haemodynamic changes, which seem to be similar to those found in phaeochromocytoma. ${ }^{5}$

The haemodynamic measurements in this patient suggested highly increased adrenergic activity: hypertension associated with decreased preload and cardiac index and severely increased systemic vascular resistance. This particular pattern was confirmed by the presence of very high plasma catecholamine concentrations, similar to those found in phaeochromocytoma. In this condition the introduction of a $\beta$ blocker with its inhibitory effects on cardiac $\beta$ receptors might be detrimental, reducing the cardiac index to values found in shock. The antihypertensive drug labetalol appears to be particularly effective in controlling sympathetic overactivity in tetanus ${ }^{6}$; with its combined $\alpha$ and $\beta$ blocking actions the risks of an unbalanced $\alpha$ stimulation are minimised.

Finally, our results show that in severe tetanus the changes in heart rate and blood pressure seem to parallel changes in catecholamine concentrations, at least during the early phase of the disease.
We thank Professor Fritz Bühler, University Hospital, Basle, for determining plasma catecholamine concentrations.

\section{References}

${ }^{1}$ Keilty SR, Gray RC, Dundee JW, et al. Catecholamine levels in severe tetanus. Lancet 1968;ii:195.

${ }^{2}$ Kerr JH, Corbett JL, Prys-Roberts C, et al. Involvement of the sympathetic nervous system in tetanus. Studies on 82 cases. Lancet 1968;ii 236-41.

${ }^{3}$ Kanarek DJ, Kaufmann B, Zwi S. Severe sympathetic hyperactivity associated with tetanus. Arch Intern Med 1973;132:602-4.

${ }^{4}$ Grossman W. Cardiac catheterization and angiography. Philadelphia: Lea and Febiger, 1974.

${ }^{5}$ Pécoud A, Francioli P, Pradervand D, et al. Haemodynamics in phaeochromocytoma. A report of 2 cases. Intensive Care Med 1979;5:143-6.

${ }^{6}$ Dundee JW, Morrow WFK. Labetalol in severe tetanus. Br Med $\mathrm{f}$ 1979;i:1121-2.

(Accepted 14 February 1984)

\title{
Serum fructosamine concentrations in patients with type II (non-insulin-dependent) diabetes mellitus during changes in management
}

\author{
JOHN R BAKER, ROGER N JOHNSON, DAVID J SCOTT
}

\begin{abstract}
The serum fructosamine concentration was examined as a new means to monitor metabolic control in non-insulindependent diabetes during changes in management. Weekly fructosamine estimations were compared with glycosylated haemoglobin $\left(\mathbf{H b} \mathbf{A}_{\mathrm{Ic}}\right), 24$ hour urinary glucose, and fasting plasma glucose concentrations in a 17 week study entailing withdrawal and reinstitution of oral treatment. The serum fructosamine concentration was more sensitive than the other measurements in detecting a deterioration in diabetic control after stopping oral hypoglycaemic drugs. The response to reinstitution of treatment was not significant in the first three weeks $(p=0 \cdot 266)$, despite a highly significant reduction in fasting plasma glucose $(p=0.001)$ and 24 hour urinary glucose concentrations $(p=0.012)$.

Compared with $\mathbf{H b A}_{\mathrm{lc}}$, concentrations of fructosamine appeared more useful in monitoring short term (three to six weeks) changes after alterations in management of diabetes. Additional advantages were lower cost and technical simplicity of measurement.
\end{abstract}

\footnotetext{
Department of Clinical Biochemistry, Green Lane Hospital, Auckland, New Zealand

JOHN R BAKER, MB, chemical pathologist

ROGER N JOHNSON, PHD, scientific officer

Academic Medical Unit, Middlemore Hospital, Otahuhu, Auckland, New Zealand

DAVID J SCOTT, FRCP, physician
}

Correspondence to: Dr John R Baker, Department of Clinical Biochemistry, Green Lane Hospital, Private Bag, Auckland, New Zealand.

\section{Introduction}

Estimating the circulating glycosylated haemoglobin $\left(\mathrm{HbA}_{\mathrm{lc}}\right)$ concentration is an accepted method for assessing long term diabetic control. ${ }^{1}$ Nevertheless, while this is a useful objective test to assess stable glycaemia, it is not well suited to monitor the rapid changes that occur with an alteration in management. ${ }^{23}$ Measurement of the concentration of glycosylated proteins in the serum provides a more rapidly responding parameter, ${ }^{4}$ although cumbersome methods of analysis discourage its routine use. ${ }^{5}$

We have described the fructosamine assay as a simple, cheap, and rapid method of measuring the serum concentration of glycosylproteins. ${ }^{6}$ The present study was undertaken to determine the clinical usefulness of fructosamine estimations in monitoring alterations in management in a group of patients with non-insulin-dependent (type II) diabetes mellitus.

\section{Patients and methods}

We studied five men and two women with mild non-insulindependent diabetes mellitus in whom random blood glucose measurements at the past three clinic visits had yielded values less than $10 \mathrm{mmol} / 1(180 \mathrm{mg} / 100 \mathrm{ml})$. All were white, and none showed clinical evidence of organic diabetic complications. The table summarises their clinical details. All patients had normal liver and renal function and normal haematological profiles. Participants gave informed consent at the outset, and the study was approved by the human ethics committee of Auckland Hospital.

Reference intervals for fructosamine, fasting plasma glucose, and $\mathrm{HbA}_{1 \mathrm{c}}$ values were determined in 30 healthy non-diabetic volunteers from the hospital laboratory aged $18-55$ years (median 28). Diabetes was rigorously excluded from this reference population using the plasma insulin and $C$ peptide responses to intravenous glucagon. ${ }^{8}$

Patients were seen weekly for 17 weeks. They took their usual medication and diet during the first five weeks and from week 11 to the completion of the study. From weeks 5 to 11 oral hypoglycaemic treatment was withdrawn. Fasting blood specimens and a 24 hour urine collection were obtained at weekly intervals. 
Clinical details of seven non-insulin-dependent diabetic patients

\begin{tabular}{|c|c|c|c|c|}
\hline $\begin{array}{l}\text { Case } \\
\text { No }\end{array}$ & $\begin{array}{c}\text { Sex and } \\
\text { age (years) }\end{array}$ & $\begin{array}{c}\text { Duration of } \\
\text { diabetes } \\
\text { (years) }\end{array}$ & $\underset{\text { index }\left(\mathrm{kg} / \mathrm{m}^{2}\right)}{\text { Body mass }}$ & Treatment \\
\hline $\begin{array}{l}1 \\
2 \\
3 \\
4 \\
5\end{array}$ & $\begin{array}{l}\text { M } 48 \\
\text { M } 64 \\
\text { F } 72 \\
M \quad 36 \\
M \quad 69\end{array}$ & $\begin{array}{r}1 \\
28 \\
11 \\
1 \\
17\end{array}$ & $\begin{array}{l}23 \cdot 9 \\
25 \cdot 6 \\
37 \cdot 3 \\
27 \cdot 5 \\
22 \cdot 2\end{array}$ & \multirow{3}{*}{$\begin{array}{l}\text { Glibenclamide } 10 \mathrm{mg} \\
\text { Glibenclamide } 10 \mathrm{mg} \\
\text { Metformin } 1 \mathrm{~g} \\
\text { Metformin } 1 \mathrm{~g} \\
\text { Glibenclamide } 15 \mathrm{mg} \text {, metformin } \\
1.7 \mathrm{~g} \\
\text { Glibenclamide } 15 \mathrm{mg} \text {, metformin } \\
1 \mathrm{~g} \\
\text { Glibenclamide } 15 \mathrm{mg} \text {, metformin } \\
1 \mathrm{~g}\end{array}$} \\
\hline 6 & M 48 & 5 & $26 \cdot 3$ & \\
\hline 7 & F 43 & 10 & $37 \cdot 3$ & \\
\hline
\end{tabular}

Fructosamine $^{6}$ was measured using a bichromatic automated analyser (Abbott Laboratories, Chicago). The within day coefficient of variation was $3.4 \%$ and between day coefficient of variation $5.0 \%$. Glucose was assayed by a hexokinase and glucose-6-phosphate dehydrogenase method $^{9}$ and $\mathrm{HbA}_{1 c}$ measured by high performance liquid chromatography. ${ }^{10}$

\section{Results}

The range of values for fructosamine in the reference population was $1.28-1.76$ (median 1.52 ) $\mathrm{mmol} / \mathrm{l}(32-44$ (median 38$) \mathrm{mg} / 100 \mathrm{ml}$ ). Fasting plasma glucose concentrations in the same subjects were 4.1-5.8 (median 5.0) $\mathrm{mmol} / \mathrm{l}(74-105$ (median 90) $\mathrm{mg} / 100 \mathrm{ml}$ ) and $\mathrm{HbA}_{\mathrm{lc}}$ values $4 \cdot 2-6 \cdot 0 \%$ (median $5 \cdot 0 \%$ ).
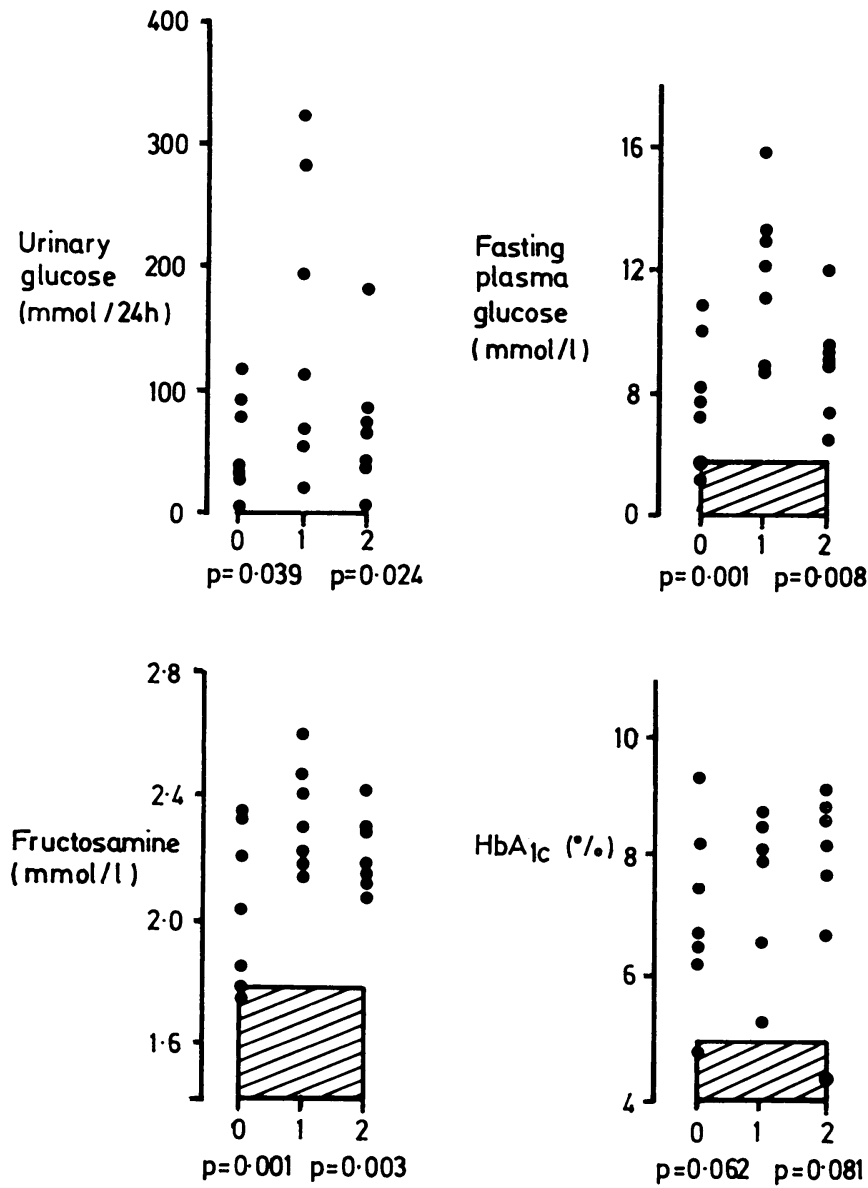

FIG 1 -Mean fructosamine, $\mathrm{HbA}_{1} \mathrm{c}$, fasting plasma glucose and urinary glucose values over baseline five weeks ( 0 ) compared with mean values during treatment withdrawal period (1), in turn compared with values obtained for treatment reinstitution period (2). First two weekly samples after changes in management omitted in each case to allow values to settle at new level. Significance $(p)$ determined by paired Student's $t$ test. Hatched areas represent reference intervals.

Conversion: SI to traditional units-Fructosamine: $1 \mathrm{mmol} / 1 \approx 25 \mathrm{mg} / 100$ ml. Plasma glucose: $1 \mathrm{mmol} / 1 \approx 18 \mathrm{mg} / 100 \mathrm{ml}$. Urinary glucose: $1 \mathrm{mmol} / 24 \mathrm{~h}$ $\approx 0.18 \mathrm{~g} / 24 \mathrm{~h}$.
Test response to changes in management-Figure 1 presents the mean results for all patients during the baseline and treatment withdrawal and treatment reinstitution periods, the first two weekly samples after changes in management being omitted in each case to allow values to settle. Fructosamine and fasting plasma glucose concentrations showed highly significant changes with both deteriorating and improving metabolic control $(p<0 \cdot 01)$. Less significant responses were observed for the other measurements. Figure 2 gives the results of serial estimation of fructosamine concentrations in one diabetic patient. Concentrations of $\mathrm{HbA}_{\mathrm{lc}}$ and urinary and fasting plasma glucose are provided to show hyperglycaemia. Withdrawal of

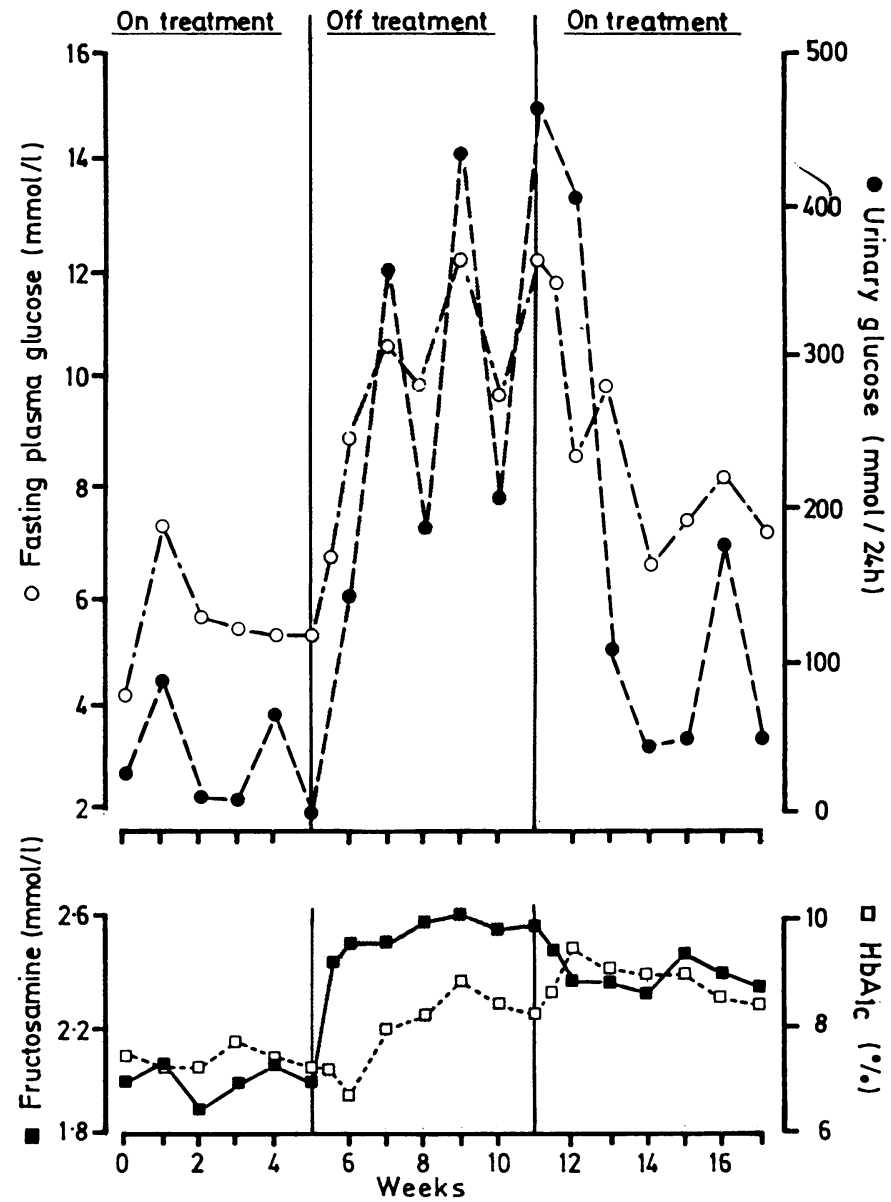

FIG 2-Fructosamine, $\mathrm{HbA}_{1} \mathrm{c}$, urinary glucose, and fasting plasma glucose concentrations in non-insulin-dependent diabetic patient after changes in management. Oral hypoglycaemic treatment withdrawn between weeks 5 and 11.

Conversion: SI to traditional units-Fructosamine: $1 \mathrm{mmol} / \mathrm{l} \approx 25 \mathrm{mg} / 100$ $\mathrm{ml}$. Plasma glucose: $1 \mathrm{mmol} / 1 \approx 18 \mathrm{mg} / 100 \mathrm{ml}$. Urinary glucose: $1 \mathrm{mmol} / 24 \mathrm{~h}$ $\approx 0.18 \mathrm{~g} / 24 \mathrm{~h}$.

treatment precipitated an abrupt increase in fructosamine concentration, which reached a plateau one to two weeks later. With the resumption of normal oral treatment at week 11 the fructosamine concentration remained raised despite a rapid decline in fasting plasma glucose and urinary glucose.

Sensitivity of measurements to alterations in treatment-Sensitivity of an analytical parameter is usually considered to be its ability to detect small stepwise increments. ${ }^{11}$ In this study the sensitivity of the four measurements was assessed by searching for significant deviations from baseline in the first three weeks after changes in management (fig 3). This incorporates the precision of the method together with the rate of response of the variable. Fructosamine was highly responsive to an abrupt deterioration in diabetic control $(p=0.0001)$ but insensitive to sudden improvement $(p=0 \cdot 266)$. Urinary and fasting plasma glucose estimations were more useful in detecting improving control than deteriorating control. This finding is attributable to the greater baseline fluctuation observed with plasma and urinary glucose measurements. $\mathrm{HbA}_{\mathrm{lc}}$ showed little baseline variation but displayed an unpredictable, sluggish response to both changes in management. 

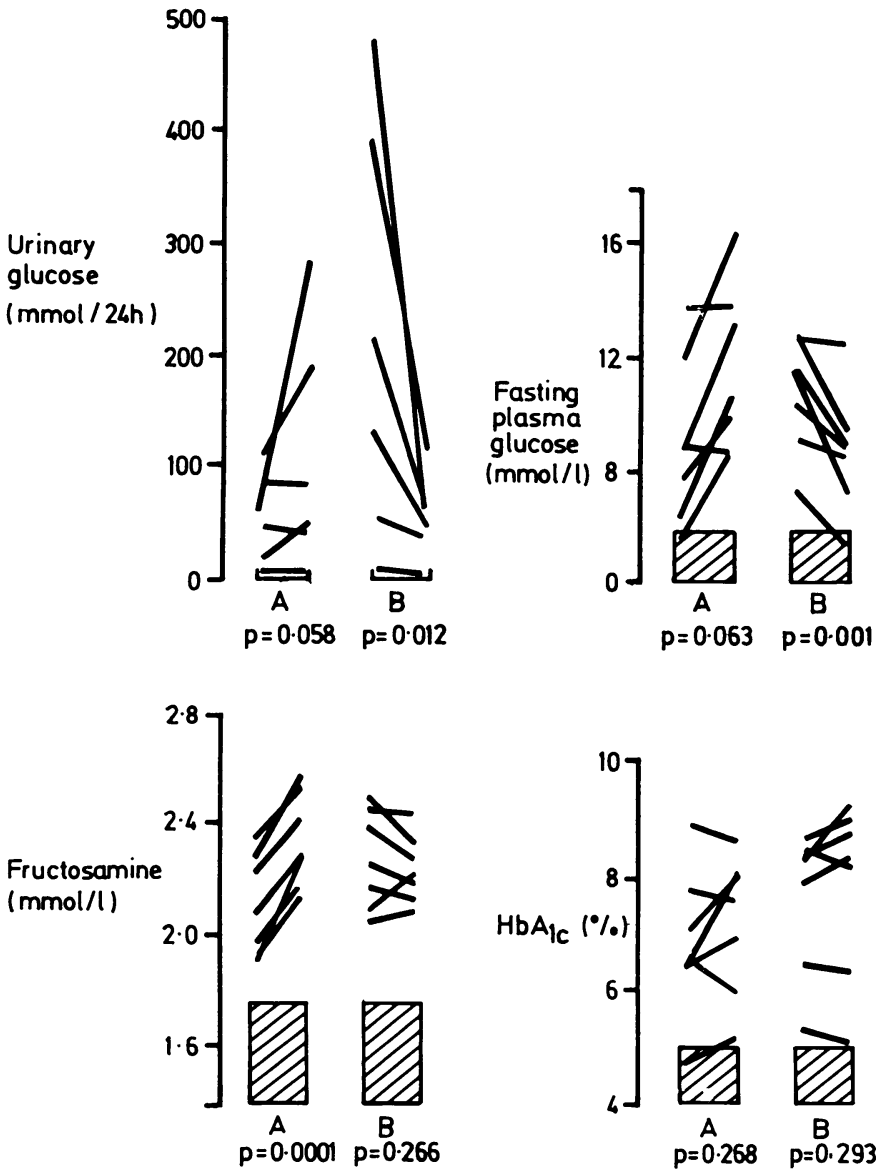

FIG 3-Rate of change of fructosamine, $\mathrm{HbA}_{1} \mathrm{c}$, fasting plasma glucose, and 24 hour urinary glucose concentrations over first three weeks after change in management $(A, B)$. Linear regression analysis of three weekly test results with time gave regression lines shown. Analysis of variance performed to confirm significant differences between slopes. Significance values (p) obtained by comparing seven individual slopes with baseline slopes (not shown) using paired Student's $t$ test. Hatched areas represent reference intervals.

Conversion: SI to traditional units-Fructosamine: $1 \mathrm{mmol} / 1 \approx 25 \mathrm{mg} / 100$ $\mathrm{ml}$. Plasma glucose: $1 \mathrm{mmol} / 1 \approx 18 \mathrm{mg} / 100 \mathrm{ml}$. Urinary glucose: $1 \mathrm{mmol} / 24 \mathrm{~h}$ $\approx 0.18 \mathrm{~g} / 24 \mathrm{~h}$.

\section{Discussion}

While the place of plasma glucose measurement at standard times throughout the day is established as a guide to modifying treatment, an accurate measure of mean blood glucose concentrations over several days or weeks would prove extremely useful in judging overall diabetic control and the response to changes in management. ${ }^{12}$ Fructosamine provides such a measurement, reflecting mainly the basal or fasting concentration with little contribution from transient postprandial hyperglycaemia. ${ }^{7}$ The small individual variation between serial measurements contributes to the very high sensitivity of fructosamine in detecting a deterioration in diabetic control (fig 3). When treatment was resumed and blood glucose control restored the initial lack of response was consistent with the notion that decay is dependent on the turnover of serum proteins. ${ }^{13}$

The pattern of changes in $\mathrm{HbA}_{\mathrm{Ic}}$ in this study differed from the findings of others, ${ }^{3}$ who reported early changes in values after alterations in management. These differences are presumably due to the labile fraction encountered in some glycosylated haemoglobin methods. ${ }^{5}$ This component caused only minimal changes to $\mathrm{HbA}_{\mathrm{ic}}$ values obtained with the high performance liquid chromatographic assay used in this study. ${ }^{14}$ The paradoxical fall in $\mathrm{HbA}_{1 \mathrm{c}}$ values after withdrawal of treatment in three patients (fig 3) was attributable to a previous episode of poor control that superseded the effects of the current study. This problem arises because of the long life span of the red cell and may further complicate the interpretation of individual $\mathrm{HbA}_{1 \mathrm{c}}$ measurements. ${ }^{15}$

All the variables examined are influenced by other factorsthe fasting plasma glucose concentration varies in response to stress or exercise, urinary glucose is modified by the renal threshold, the $\mathrm{HbA}_{\mathrm{lc}}$ value depends on red cell turnover, and fructosamine is influenced by alterations in serum protein metabolism. ${ }^{7}$ Nevertheless, in this study fructosamine seemed less affected by extraneous factors than the other measurements. If these observations are confirmed the high sensitivity for detecting deteriorating diabetic control and a half life of two to three weeks ${ }^{7}$ confer highly desirable clinical properties on this variable.

We thank Mrs P Metcalf and Mrs C Breed for technical help. Dr D Jury for the $\mathrm{HbA}_{\mathrm{lc}}$ analyses, and $\mathrm{Dr} \mathrm{P}$ Dunn for advice and encouragement. JRB was supported by the New Zealand Diabetes Association.

\section{References}

1 Anonymous. Haemoglobin $\mathrm{A}_{1}$ and diabetes: a reappraisal. [Editorial.] $\mathrm{Br}$ Med F $1980 ; 281: 1304-5$.

2 Graf RJ, Halter JB, Porte D. Glycosylated hemoglobin in normal subjects and subjects with maturity-onset diabetes. Evidence for a saturable system in man. Diabetes 1978;27:834-9.

3 Boden G, Master RW, Gordon SS, Shuman CR, Owen OE. Monitoring metabolic control in diabetic outpatients with glycosylated hemoglobin. Ann Intern Med 1980;92:357-60.

4 Kennedy AL, Merimee J. Glycosylated serum protein and hemoglobin $\mathrm{A}_{1}$ levels to measure control of glycemia. Ann Intern Med 1981;95:56-8.

5 Mayer TK, Freedman ZR. Protein glycosylation in diabetes mellitus: a review of laboratory measurements and of their clinical utility. Clin Chim Acta 1983;127:147-84.

6 Johnson RN, Metcalf PA, Baker JR. Fructosamine: a new approach to the estimation of serum glycosylprotein. An index of diabetic control. Clin Chim Acta 1983;127:87-95.

7 Baker JR, O'Connor JP, Metcalf PA, Lawson MR, Johnson RN. Clinical usefulness of estimation of serum fructosamine concentration as a screening test for diabetes mellitus. $\mathrm{Br} M e d \mathcal{F} 1983 ; 287: 863-7$.

${ }^{8}$ Madsbad S, Krarup T, McNair P, et al. Practical clinical value of the C-peptide response to glucagon stimulation in the choice of treatment in diabetes mellitus. Acta Med Scand 1981;210:153-6.

${ }^{9}$ Neese JW, Duncan P, Bayse D, Robinson M, Cooper T, Stewart C. Development and evaluation of a hexokinase/glucose-6-phosphate dehydrogenase procedure for use as a national glucose reference method. Washington: US Department of Health Education and Welfare, 1976. (Publication No (CDC) 77-8330.)

10 Cole RA, Soeldner JS, Dunn PJ, Bunn HF. A rapid method for the determination of glycosylated hemoglobins using high pressure liquid chromatography. Metabolism 1978;27:289-301.

11 Varley H, Gowenlock AH, Bell M. Practical clinical biochemistry. Vol 1. London: William Heinemann, 1980.

12 Tattersall R, Walford S, Peacock I, Gale E, Allison S. A critical evaluation of methods of monitoring diabetic control. Diabetes Care 1980;3:150-4.

13 Schultze HE, Heremans JF. Molecular biology of human proteins with special reference to plasma proteins. Vol 1. Amsterdam: Elsevier.

14 Jury DR, Baker JR, Dunn PJ. Clinical importance of the reversible fraction of haemoglobin $A_{1}$ in type II (non-insulin dependent) diabetes mellitus. Diabetologia $1983 ; 25: 313-5$.

15 Boucher BJ, Welch SG. Measuring glycosylated haemoglobin concentrations in a diabetic clinic. $\mathrm{Br}$ Med $\mathcal{F} 1981 ; 282: 150$.

(Accepted 2 February 1984) 